\title{
Insulin-gene flanking sequences, diabetes mellitus and atherosclerosis: a review
}

\author{
T. Mandrup-Poulsen ${ }^{1}$, D. Owerbach ${ }^{1,3}$, J. Nerup ${ }^{1}$, K. Johansen ${ }^{1}$, J. Ingerslev ${ }^{2}$ and A. Tybjærg Hansen ${ }^{1}$ \\ ${ }^{1}$ Steno Memorial Hospital and Hagedorn Research Laboratory, Gentofte, ${ }^{2}$ Medical Department C, Copenhagen County Hospital, \\ Glostrup, Denmark and ${ }^{3}$ University of Massachusetts, Medical School, Worcester, USA
}

\begin{abstract}
Summary. A highly polymorphic locus flanking the human insulin gene contains two major size classes of DNA restriction fragments, which segregate in families as stable genetic elements. The L-allele, i.e. fragments with an average size of about 600 base-pairs seems to be a weak genetic marker for Type 1 (insulin-dependent) diabetes mellitus, whereas the Uallele, i.e. fragments of an average size of about 2500 basepairs hitherto has been associated with Type 2 (non-insulindependent) diabetes mellitus and diabetic hypertriglyceridaemia. The most recent reports on this subject do not confirm
\end{abstract}

an association between the U-allele and Type 2 diabetes. Our own studies indicate that the U-allele is a fairly strong marker for the development of atherosclerosis (relative risk for U-carriers 3.36). The putative functions of the polymorphic region in atherogenesis and the relation of this region to other genetic markers for atherosclerosis are not known.

Key words: Insulin-gene, DNA-polymorphisms, diabetes mellitus, atherosclerosis, genetic markers, molecular genetics.
During the last few years, developments within the field of recombinant-DNA technology have greatly increased our knowledge concerning the localization, structure and function of genes, and molecular genetics are being increasingly applied in clinical research and diagnostic medicine [1].

Since Type 2 diabetes is probably a heterogeneous group of disorders, we and others have used this new technology as related to the insulin-gene in the search for the genetic basis and possibly the aetiology of Type 2 diabetes. As demonstrated in this review, the effort is so far in vain, but it has revealed an intriguing association between a peculiar polymorphic DNA-region flanking the human insulin-gene and atherosclerotic macrovascular disease. This association occurs in Type 1 and Type 2 diabetic patients as well as in non-diabetic subjects.

\section{The structure and function of the human insulin-gene and its flanking regions}

The amino-acid-sequence of human insulin has been known since 1959 [2], but it was not until 1980 that the nucleotide-sequence of the human insulin-gene was determined [3].
The human insulin-gene is located in band $p 15$ of the short arm of chromosome $11[4,5]$. The insulin-gene proper consists of a coding sequence which codes for a 1430-nucleotide messenger-RNA precursor, and is interrupted by two intervening sequences of 179 and 786 nucleotides, respectively (introns) (Fig. 1) [3]. After excision of the two intervening sequences, the messenger RNA molecule for pre-proinsulin is formed.

The structure of the insulin-gene flanking DNAsequences has also been determined recently (Fig.1). About 6,000 basepairs (bp) downstream $\left(3^{\prime}\right)$ and $15,000 \mathrm{bp}$ upstream $\left(5^{\prime}\right)$ to the insulin-gene are regions consisting of repetitive sequences, members of the socalled Alu-family $[6,7]$. The Alu-family members are 300 -bp repetitions, which comprise $3 \%$ of the total human DNA, distributed in the whole genome [8]. The function of the Alu-family is unknown, but these sequences are considered to flank active regions of chromatin [9]. The Alu-family sequences and the 3'-region are non-polymorphic $[6,7]$, whereas the $5^{\prime}$-region is highly polymorphic, i. e. variable in length [6]. The polymorphic $5^{\prime}$-region starts only 363 bp upstream to the insulin-gene.

DNA fragments containing the $5^{\prime}$-region can be obtained by cutting the short arm of chromosome 11 into small pieces by means of restriction enzymes (see be- 


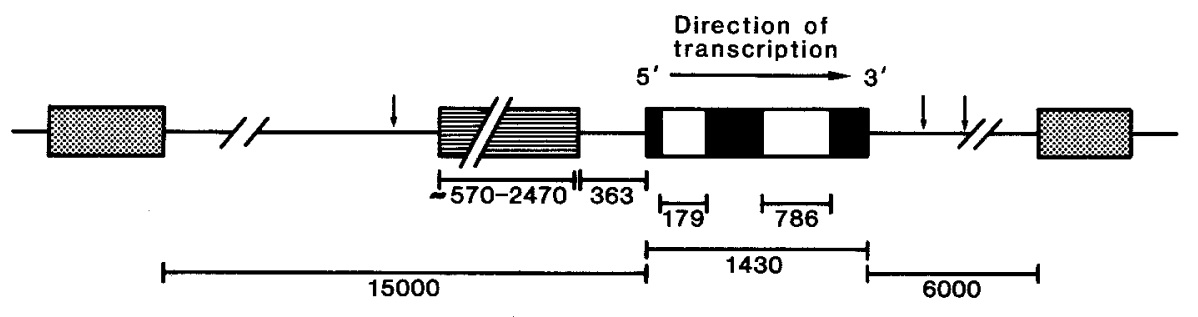

Fig. 1. Organization of the insulin gene and flanking regions. Arrows indicate BgPI restriction sites. Distances noted in base pairs. Modified after Bell et al. [7]. Insulin-gene mRNA coding region; $\square$ Insulin-gene intervening sequence; 囬 Polymorphic locus; 图 Alu-family repeated sequence
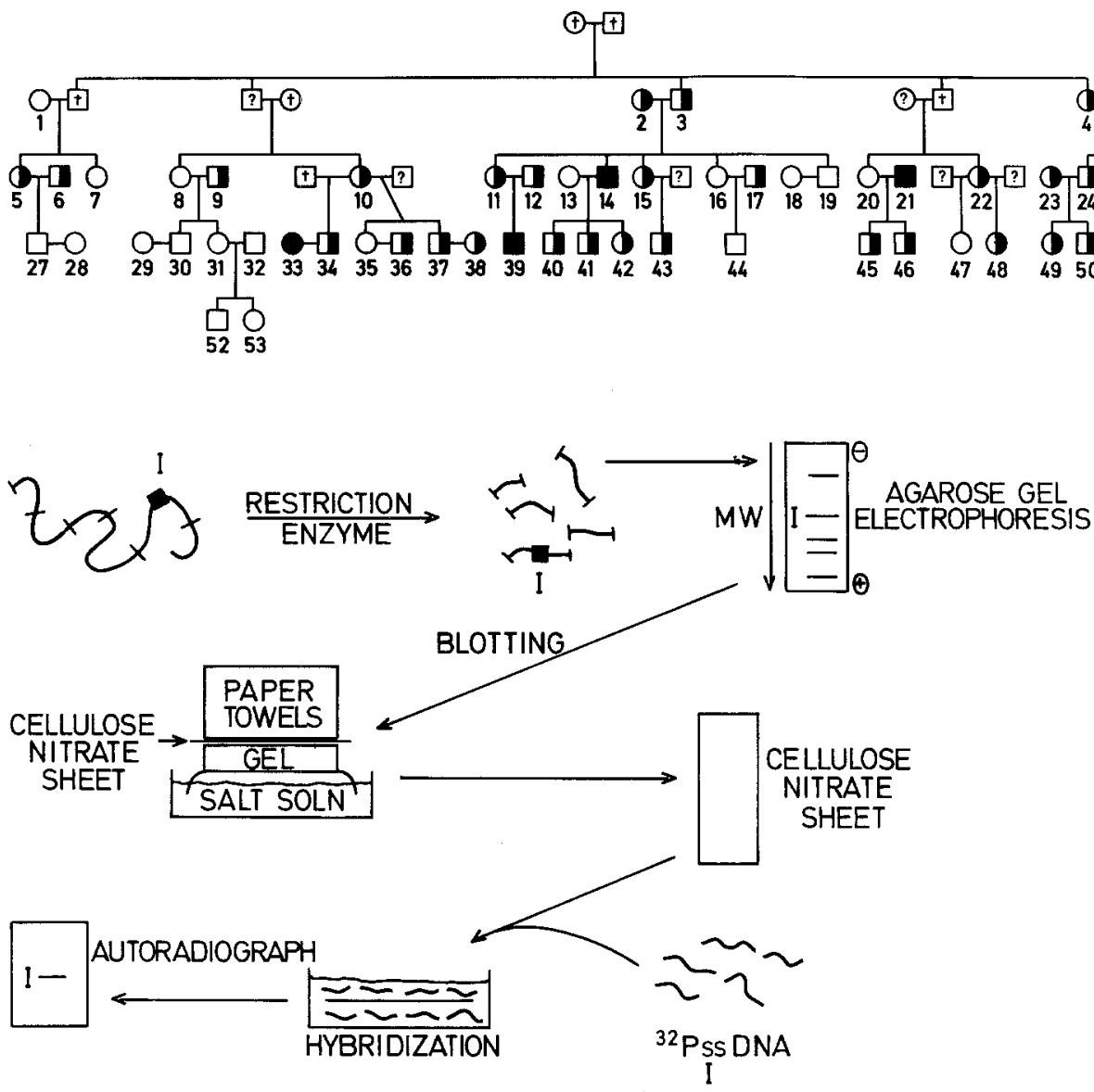

Fig. 2. Distribution of $U$ and $L$ alleles in a large family [16]. $\square \mathrm{UU}$; (1) UL; $\square$ O LL; $\oplus \oplus$ Dead; 궁 Not tested
Fig. 3. Schematic flow-chart displaying the method of DNA-restriction fragment length analysis (see text) low). The fragments containing the $5^{\prime}$-region can be divided into three main size-classes by their length. The average sizes of the three major size classes are $570 \mathrm{bp}$ (class 1), $1320 \mathrm{bp}$ (class 2), and $2470 \mathrm{bp}$ (class 3 ) [7]. The length polymorphism is due to variation in the number of repetitions of a 14-bp oligonucleotide with the concensus sequence ACAGGGGTGTGGGG [10, 11, 13]. This particular type of repetitive sequence is unique in the genome. Thus, on average, class 1 fragments contain 40, class 295 and class 3170 copies of this oligonucleotide.

There are racial differences in the distribution of the size-classes of the restriction-fragments [7, 12]. Class 2 fragments occur in $<1 \%$ of Caucasoids, in contrast to $22 \%$ of Blacks, and class 3 fragments are frequent in Caucasoids but rare in Asians.

Thus, in Caucasoids the $5^{\prime}$-region can be considered to be a locus with 2 "alleles", class 1 and class 3 , or, in the terminology of Owerbach and Nerup, L-allele (for lower electrophoretic pattern) and U-allele (for upper electrophoretic pattern), respectively. The L- and U-alleles are stable genetic elements and they segregate in families according to Mendelian laws (Fig. 2) [13, 14].

Due to the close proximity of the polymorphic region to the start of the insulin-gene coding sequence, it has been speculated that the two alleles influence the function of the insulin-gene, e.g. by exerting different degrees of control on the transcription of the insulingene. In both related and non-related non-diabetic members of a large family, the mean blood glucose concentrations, as measured by glycosylated haemoglobin $\left(\mathrm{HbA}_{1 \mathrm{c}}\right)$ [15] were higher in U-allele carriers than in Lallele carriers [16]. We do not know whether this difference in the glucose regulation is due to a primary effect of the U-allele on the function of the insulin-gene. Studies of the effect of the U- and L-alleles on the function of the insulin-gene in isolated human islets from U/L-typed necrodonors would elucidate this question, 


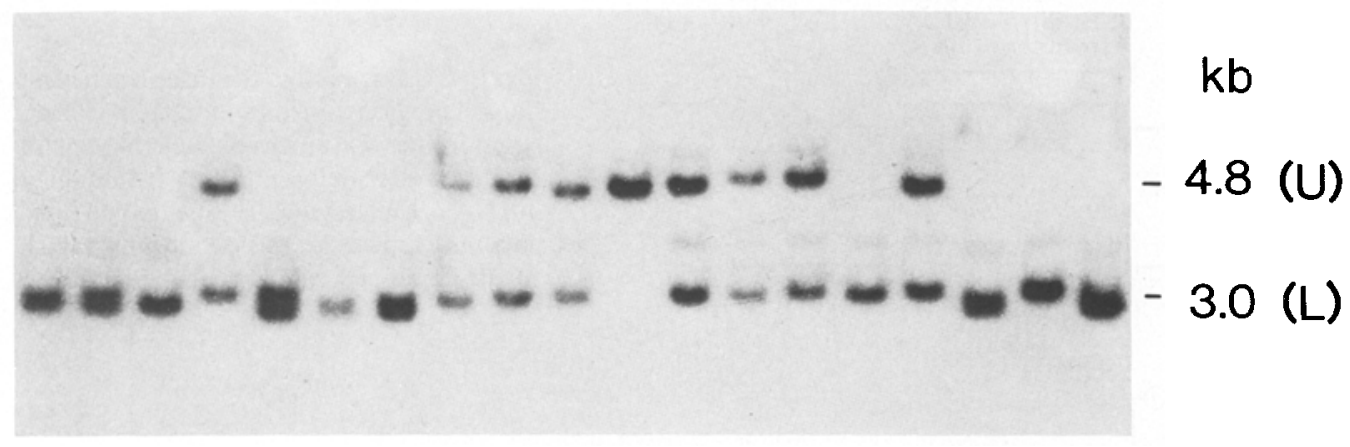

\section{$a b c d$ ef $g h$ i $j$ l m n o p q r s}

Fig.4. Autoradiogram of nitrocellulose-filters with separated BgPI restriction fragments hybridized with ${ }^{32} \mathrm{P}-1$ labelled insulin gene probes. The two major size classes $U$ and $L$ are evident. The UU, UL, and LL genotypes are represented in lanes $k, d$, and a, respectively

but such studies have not been published. However, the secretory capacity of the $\beta$ cells was not found to be related to the U-allele in either Type 2 diabetic or non-diabetic individuals [17].

Several recent clinical studies have suggested associations between the polymorphic region as genetic marker and different human disease states. In the following we will give a brief summary of the methods used for typing individuals with regard to restrictionfragment length polymorphism flanking the insulingene, and discuss the rather surprising development in the clinical associations of this new genetic marker.

\section{Methods used}

Leucocyte DNA (100-300 $\mu \mathrm{g})$ is isolated from about $10 \mathrm{ml}$ of venous blood. DNA $(1-3 \mu \mathrm{g})$ is digested by means of restriction enzymes, i.e. DNA-nucleases, which cut the DNA-helix at sites where the enzyme recognizes a particular nucleotide sequence specific for the particular restriction enzyme. In our studies, the enzyme used was BglI, but other enzymes have been applied to the study of the insulin-gene polymorphism, e.g. EcoRI, BgPII, SacI, etc. BgPI digests DNA into fragments which are suitable for the separation of the different size classes of DNA fragments in the $5^{\prime}$-region. The recognition-sites of BgPI are indicated in Figure 1. Restriction fragments in BgPI-digests will include fragments from the entire genome, but the fragments of the region close to the insulin-gene will contain both the insulin-gene proper and the 5 -region.

The double-stranded restriction-fragments are then separated by agarose-gel electrophoresis according to size, and are transferred to nitrocellulose filters by Southern blotting (Fig. 3). In this step the double helix of the DNA is unwinded, and the double-stranded DNA-fragments are converted to single-stranded DNA-fragments. These fragments are then incubated with radioactively $\left({ }^{32} \mathrm{P}\right)$-labelled insulin-gene probes. Gene-probes are genomic, cDNA, or synthetic single-
Table 1. UU, UL and LL genotype-frequencies in Type 2 and Type 1 diabetic patients and control groups

\begin{tabular}{llll}
\hline & UU & UL & LL \\
\hline $\begin{array}{l}\text { Type } 2 \text { diabetic patients } \\
(n=47)\end{array}$ & $8(17 \%)$ & $17(36 \%)$ & $22(47 \%)$ \\
$\begin{array}{l}\text { Type } 1 \text { diabetic patients } \\
(n=37)\end{array}$ & $1(3 \%)$ & $9(24 \%)$ & $27(73 \%)$ \\
$\begin{array}{c}\text { Blood donors } \\
(n=56)\end{array}$ & $4(7 \%)$ & $21(38 \%)$ & $31(55 \%)$ \\
$\begin{array}{c}\text { Normal glucose tolerance } \\
(n=29)\end{array}$ & $0(0 \%)$ & $16(55 \%)$ & $13(45 \%)$ \\
\hline
\end{tabular}

UU + UL versus LL: Type 2 versus Type 1 diabetic patients $(n p=$ 0.026 , Fisher's exact test). Type 2 diabetic patients versus blood donors (NS). Type 2 diabetic patients versus normal glucose tolerance $(p=0.0333)$. Type 1 diabetic patients versus normal glucose tolerance $(p=0.014)$. Data from [14] and [20]

stranded DNA-sequences which are identical or widely homologous to parts of the gene or the whole gene in question. The separated single-stranded DNA-fragments, containing the insulin-gene in the digest will bind to (hybridize with) the complementary, radioactively-labelled insulin-gene probes; those electrophoresis-bands which contain the insulin-gene (and other fragments of the same size) may then be visualized by autoradiography of the hybridized nitrocellulose-filters (Fig.4). The size (length) of the DNA-fragments containing the insulin-gene can be determined by comparing the localization of the bands on the autoradiogram with the localization of standards of known size run in parallel on the gel.

\section{Associations between the U/L-alleles and different disease entities}

\section{Diabetes mellitus}

Diabetes mellitus is a heterogeneous group of disorders characterized by abnormal glucose metabolism. The recognition of Type 1 (insulin-dependent) diabetes and 
Table 2. UU, UL and LL genotype frequencies in four samples of Caucasoid Type 2 diabetic patients and non-diabetic control subjects

\begin{tabular}{|c|c|c|c|c|c|c|c|c|}
\hline & \multicolumn{4}{|c|}{ Non-diabetic subjects } & \multicolumn{4}{|c|}{ Type 2 diabetic patients } \\
\hline & UU & UL & LI. & Total & UU & UL & LI & Total \\
\hline San Francisco [7] & 8 & 38 & 37 & 83 & 4 & 24 & 48 & 76 \\
\hline St. Louis [12] & 0 & 12 & 21 & 33 & 1 & 14 & 19 & 34 \\
\hline Copenhagen $[14,20]$ & 0 & 16 & 13 & 29 & 8 & 17 & 22 & 47 \\
\hline London [21] & 7 & 44 & 37 & 88 & 20 & 32 & 19 & 71 \\
\hline Total & $\begin{array}{l}15 \\
(6 \%)\end{array}$ & $\begin{array}{l}110 \\
(47 \%)\end{array}$ & $\begin{array}{l}108 \\
(46 \%)\end{array}$ & $\begin{array}{l}233 \\
(100 \%)\end{array}$ & $\begin{array}{l}33 \\
(15 \%)\end{array}$ & $\begin{array}{l}87 \\
(38 \%)\end{array}$ & $\begin{array}{l}108 \\
(47 \%)\end{array}$ & $\begin{array}{l}228 \\
(100 \%)\end{array}$ \\
\hline
\end{tabular}

UU + UL versus LL: non-diabetic subjects versus Type 2 diabetic patients (NS). Allelic frequency of U: non-diabetic subjects versus Type 2 diabetic patients (NS)

Table 3. UU + UL and LL genotype frequencies in Type 2 diabetic patients and non-diabetic control subjects in relation to macroangiopathy

\begin{tabular}{|c|c|c|c|c|}
\hline & \multicolumn{2}{|c|}{$\begin{array}{l}\text { Type } 2 \text { diabetic } \\
\text { patients }\end{array}$} & \multicolumn{2}{|c|}{$\begin{array}{l}\text { Non-diabetic control } \\
\text { subjects }\end{array}$} \\
\hline & $U U+U L$ & LL & $\mathrm{UU}+\mathrm{UL}$ & $\mathrm{LL}$ \\
\hline $\begin{array}{l}\text { Total number } \\
\text { of subjects }\end{array}$ & 25 & 22 & 38 & 36 \\
\hline $\begin{array}{l}\text { Number with } \\
\text { macroangiopathy }\end{array}$ & $\begin{array}{l}13 \\
(52 \%)\end{array}$ & $\begin{array}{c}6 \\
(27 \%)\end{array}$ & $\begin{array}{l}18 \\
(47 \%)\end{array}$ & $\begin{array}{c}4 \\
(11 \%)\end{array}$ \\
\hline $\begin{array}{l}\text { Number without } \\
\text { macroangiopathy }\end{array}$ & $\begin{array}{c}12 \\
(48 \%)\end{array}$ & $\begin{array}{l}16 \\
(73 \%)\end{array}$ & $\begin{array}{l}20 \\
(53 \%)\end{array}$ & $\begin{array}{l}32 \\
(89 \%)\end{array}$ \\
\hline
\end{tabular}

Frequency of genotypes UU $+\mathrm{UL}$ versus genotype LL in Type 2 diabetic patients with macroangiopathy versus Type 2 diabetics without macroangiopathy $(13: 6$ versus $12: 16 ; p=0.11)$. UU versus $L L$ in the same groups $(6: 6$ versus $2: 16 ; p=0.0483)$. UU + UL versus $L L$ in control subjects with macroangiopathy versus control subjects without macroangiopathy ( $18: 4$ versus $20: 32 ; p=0.001)$. UU + UL versus LL in Type 2 diabetic patients without macroangiopathy versus control subjects without macroangiopathy (12:16 versus 20:32; NS). Two-tailed Fisher's exact test. Data from [20]

Table 4. Clinical diagnoses of non-atherosclerotic control subjects

\begin{tabular}{ll}
\hline Diagnoses & No \\
\hline Variant angina & 5 \\
Adams-Stokes syndrome & 1 \\
Non-characteristic chest pain & 5 \\
Aortic insufficiency & 4 \\
Combined aortic-mitral insufficiency & 1 \\
Coarctation of the aorta & 1 \\
Abnormal exercise ECG & 1 \\
Oesophageal spasm & 2 \\
Gall stone & 1 \\
\hline
\end{tabular}

Data from [35]

Type 2 (non-insulin-dependent) diabetes as genetically different diseases was not possible until the discovery of the association between Type 1 diabetes and the HLAregion on the short arm of chromosome 6 [18].

Type 2 diabetes. Family- and twin-studies indicate a strong heredity of Type 2 diabetes, but thus far it has not
Table 5. Allelic frequency of $\mathrm{U}$ in atherosclerotic and non-atherosclerotic individuals

\begin{tabular}{llll}
\hline & Males & Females & Total \\
\hline $\begin{array}{c}\text { Atherosclerotic } \\
(n=41)\end{array}$ & 0.29 & 0.42 & 0.30 \\
$\begin{array}{c}\text { Non-atherosclerotic } \\
(n=21)\end{array}$ & 0.15 & 0.09 & 0.12 \\
\hline$p$-value (Fisher) & $(3 / 20)$ & $(2 / 22)$ & $(5 / 42)^{\mathrm{a}}$ \\
\hline
\end{tabular}

Data from [36]. ${ }^{a}$ The total number of alleles at the locus concerned is twice the number of subjects genotyped; the allelic frequency of $U$ is the frequency of this allele expressed as a proportion of the total

been possible to identify genetic markers for Type 2 diabetes.

The finding of the polymorphic region so close to the insulin-gene led to several studies of a possible association between this region and Type 2 diabetes, because a putative effect of the different size-classes of sequences on the expression of the insulin-gene was an attractive explanation for, at least, subtypes of Type 2 diabetes with decreased insulin-secretion or secretion of an abnormal insulin-molecule as pathogenetic features. These studies were carried out almost simultaneously in San Francisco, USA [6], St. Louis, USA [19], and Gentofte, Denmark [14].

Bell et al. were unable to demonstrate differences in the distribution of $U$ - and L-alleles in a small sample of Type 2 and Type 1 diabetic patients which was compared with non-diabetic control subjects [6]. Two studies published almost simultaneously demonstrated an association between the $\mathrm{U}$-allele and Type 2 diabetes. Rotwein et al. [19] found a significantly higher frequency of the genotypes UU and UL in Type 2 diabetic patients than in non-diabetic control subjects, whereas Owerbach and Nerup [14] found a significant excess of UU and UL genotypes in Type 2 diabetic patients when compared with Type 1 diabetic patients, but not when compared with the control group. The control subjects comprised a group of blood-donors who were not tested for impaired glucose-tolerance (Table 1). By comparing the genotype-distribution in the same sample of 
Type 2 diabetic patients with that in an age-matched control group (with normal glucose-tolerance throughout a follow-up period of 17 years) (Table 1), the association between the U-allele and Type 2 diabetes was apparently confirmed [20]. This result has recently been independently supported by Hitman et al. [21].

By pooling data on Caucasoids from San Francisco, St. Louis, London and Gentofte no significant association between Type 2 diabetes and the U-allele can be demonstrated (Table 2).

Interestingly, no association between the U-allele and Type 2 diabetes was seen in two populations with high prevalence of Type 2 diabetes: Nauruans [22] and Pima Indians [23].

Maturity-onset diabetes in the young. Maturity-onset diabetes in the young (MODY) is a distinct disease-entity characterized by a mild, non-insulin-dependent diabetes with few microvascular complications and onset in youth. The disease is inherited as an autosomal dominant trait and thus it was appropriate to look for an association between MODY and the polymorphic insulin-gene-flanking region. Several studies have not been able to demonstrate any association between MODY and the U/L-alleles [24-27]. This lack of association was demonstrated by formal linkage analysis [24] and was later confirmed [27].

Type 1 diabetes. The genetic association between Type 1 diabetes and the HLA-antigens D/DR3 and/or DR4 approaches $100 \%$ [28]. Thus, it is unlikely that other disease-susceptibility genes for Type 1 diabetes exist outside the HLA-region on the short arm of chromosome 6. Nevertheless, the LL-genotype frequency in Type 1 diabetic patients studied by Owerbach and Nerup [14, 20] was $73 \%$ versus $45 \%$ in non-diabetic control subjects tested for glucose-intolerance $(p=0.014$, Table 1$)$. In a recent study of 113 Type 1 diabetic patients, Bell et al. demonstrated a strong association between the L-allele and Type 1 diabetes [7], and by pooling data on Caucasoid Type 1 diabetic patients from the two American and the Danish study populations, the statistical significance of this association was strengthened.

\section{Hypertriglyceridaemia}

A polymorphic region adjacent to the Apo-A1-lipoprotein-gene on the long arm of chromosome 11 [29] has been shown to be related to hypertriglyceridaemia (HTG) and this particular polymorphism segregates with the disease in families [30]. However, the ApoA1-lipoprotein-gene-flanking DNA-polymorphism is only part of the polygenic background of HTG. In the search for additional genetic markers for HTG, Jowett et al. [31] reported an association between HTG and the large size-class U-allele of the insulin-gene flanking polymorphism. When these patients were subdivided on the basis of glucose-tolerance, it was only hypertriglyceridaemic patients with impaired glucose-tolerance who had an increased frequency of the U-allele [32]. Since analysis of the lipid- and lipoproteinstatus of the Type 2 diabetic patients included in the previously-cited study populations had not been carried out in detail, Jowett et al. proposed that the association between the U-allele and Type 2 diabetes was secondary to the association between the U-allele and diabetic HTG [32].

\section{Atherosclerosis}

The Type 2 diabetic patients in the study-population of Owerbach and Nerup $[14,20]$ were carefully characterized with regard to late diabetic complications. These investigators noted a higher prevalence of atherosclerotic macrovascular disease (diabetic macroangiopathy) in Type 2 diabetic patients carrying the UU- and ULgenotypes than in Type 2 diabetic patients with the LLgenotype [14]. When the standardized WHO questionnaire for cardiovascular surveys [33] was used to collect information about previous acute myocardial infarction, cerebrovascular insults, classical symptoms of angina pectoris or claudication of the lower extremities in these patients and their controls, and hospital records were used to support the questionnaires, this originally clinical observation was confirmed [20]. To their surprise these investigators found a similar relationship between macrovascular disease and the U-allele in the non-diabetic control population (Table 3) [20]. These results indicated that the U-allele was associated with atherosclerosis (and not only the diabetic subtype of macroangiopathy), and suggested that the Type 2 diabetes-U-allele association was in fact due to the high prevalence of atherosclerosis in Type 2 diabetes and not, as previously thought, a primary association between Type 2 diabetes and the U-allele. Since the prevalence of both artherosclerosis and Type 2 diabetes increases with age, the selection of a study-population of Type 2 diabetic patients will necessarily select patients who have a high prevalence of atherosclerosis and vice versa.

Thus, it was decided to investigate the association between the U-allele and atherosclerosis in patients and controls who were carefully characterized with regard to atherosclerosis and who were tested for abnormal glucose-metabolism. Only patients with normal glucose metabolism were included.

Of a group of 429 patients who had coronary angiography [34] performed during the period 1977-1983 at the University Hospital of Copenhagen, patients with verified coronary atherosclerosis, i. e. intermediary or severe stenosis of two or three coronary vessels, were randomly selected for this study.

Since previous studies had shown that a group of individuals selected as a random sample of the elderly background population would have a high prevalence of atherosclerosis ( $\sim 30 \%$ as assessed from question- 
Table 6. Some cardiovascular risk-factors in atherosclerotic and nonatherosclerotic subjects

\begin{tabular}{|c|c|c|c|}
\hline & \multicolumn{2}{|c|}{ Study group } & \multirow[t]{2}{*}{$p$} \\
\hline & $\begin{array}{l}\text { Athero- } \\
\text { sclerotic }\end{array}$ & $\begin{array}{l}\text { Non- } \\
\text { athero- } \\
\text { sclerotic }\end{array}$ & \\
\hline $\begin{array}{l}\text { Triglyceride before } \\
\text { coronary angiography } \\
(\mathrm{mmol} / \mathrm{l})\end{array}$ & $\begin{array}{l}2.4 \\
(0.8-12.2) \\
(n=41)\end{array}$ & $\begin{array}{l}1.4 \\
(0.5-2.0) \\
(n=17)\end{array}$ & $<0.05$ \\
\hline $\begin{array}{l}\text { Triglyceride after } \\
\text { coronary angiography } \\
(\mathrm{mmol} / \mathrm{l})\end{array}$ & $\begin{array}{l}1.8 \\
(0.6-5.4) \\
(n=21)\end{array}$ & $\begin{array}{l}1.7 \\
(0.9-2.9) \\
(n=13)\end{array}$ & NS \\
\hline $\begin{array}{l}\text { Cholesterol before } \\
\text { coronary angiography } \\
(\mathrm{mmol} / \mathrm{l})\end{array}$ & $\begin{array}{l}7.0 \\
(4.5-9.5) \\
(n=41)\end{array}$ & $\begin{array}{l}6.6 \\
(4.6-9.3) \\
(n=20)\end{array}$ & NS \\
\hline $\begin{array}{l}\text { Cholesterol after } \\
\text { coronary angiography } \\
(\mathrm{mmol} / \mathrm{l})\end{array}$ & $\begin{array}{l}6.8 \\
(4.4-11.0) \\
(n=21)\end{array}$ & $\begin{array}{l}7.3 \\
(5.3-9.8) \\
(n=13)\end{array}$ & NS \\
\hline $\begin{array}{l}\text { HDL } \\
(\mathrm{mmol} / 1)\end{array}$ & $\begin{array}{l}1.3 \\
(0.7-1.9) \\
(n=21)\end{array}$ & $\begin{array}{l}1.6 \\
(1.1-2.4) \\
(n=13)\end{array}$ & $<0.02$ \\
\hline $\begin{array}{l}\text { VLDL } \\
\qquad(\mathrm{mmol} / \mathrm{l})\end{array}$ & $\begin{array}{l}1.7 \\
(0-3.1) \\
(n=21)\end{array}$ & $\begin{array}{l}0.9 \\
(0.1-2.3) \\
(n=13)\end{array}$ & $<0.05$ \\
\hline $\begin{array}{l}\text { LDL } \\
\quad(\mathrm{mmol} / 1)\end{array}$ & $\begin{array}{l}4.8 \\
(2.5-7.5) \\
(n=21)\end{array}$ & $\begin{array}{l}4.5 \\
(2.3-7.2) \\
(n=13)\end{array}$ & NS \\
\hline $\mathrm{C}^{\mathrm{F}}$ allelic frequency & $\begin{array}{l}0.17 \\
(14 / 84) \\
(n=42)\end{array}$ & $\begin{array}{l}0.26 \\
(11 / 42) \\
(n=21)\end{array}$ & NS \\
\hline $\begin{array}{l}\mathrm{HbA}_{1 \mathrm{c}} \\
\quad(\%)\end{array}$ & $\begin{array}{l}5.69 \\
(4.9-6.4) \\
(n=42)\end{array}$ & $\begin{array}{l}5.65 \\
(4.1-6.3) \\
(n=21)\end{array}$ & NS \\
\hline $\begin{array}{l}\text { Fasting blood glucose } \\
\quad(\mathrm{mmol} / \mathrm{l})\end{array}$ & $\begin{array}{l}5.07 \\
(3.8-6.3) \\
(n=42)\end{array}$ & $\begin{array}{l}5.03 \\
(4.1-6.6) \\
(n=20)\end{array}$ & NS \\
\hline $\begin{array}{l}\text { Tobacco consumption } \\
\text { (kg/lifetime) }\end{array}$ & $\begin{array}{l}231 \\
(0-482) \\
(n=38)\end{array}$ & $\begin{array}{l}148 \\
(0-547) \\
(n=21)\end{array}$ & $<0.02$ \\
\hline $\operatorname{Sex}$ ratio $(M: F)$ & $35: 6$ & $10: 11$ & $<0.002$ \\
\hline
\end{tabular}

Data from [36]. Values are given as means (range)

Table 7. Allelic frequency of $U$ as a function of age in unrelated subjects with normal glucose tolerance

\begin{tabular}{cl}
\hline Age group & Allelic frequency of $\mathrm{U}$ \\
\hline $\begin{array}{c}34 \text { years }^{\mathrm{a}} \\
(n=10)\end{array}$ & $0.40(8 / 20)$ \\
$\begin{array}{c}67 \text { years }^{\mathrm{b}} \\
(n=52)\end{array}$ & $0.27(28 / 104)$ \\
$\begin{array}{c}85 \text { years }^{\mathrm{c}} \\
(n=70)\end{array}$ & $0.23(32 / 140)$ \\
\hline
\end{tabular}

The allelic frequencies of $U$ are given as percent of total; in parentheses are given the allelic frequencies of $U$ expressed as the proportion of the total (see footnote to Table 5). The three age-groups comprise healthy subjects of identical age. Data from ${ }^{\mathrm{a}}[16] ;{ }^{\mathrm{b}}[36] ;{ }^{\mathrm{c}}$ unpublished observations
Table 8. UU + UL genotype frequency in non-diabetic, atherosclerotic patients and in non-atherosclerotic Type 2 diabetic patients versus control subjects

\begin{tabular}{cllll}
\hline & \multicolumn{2}{l}{$\begin{array}{l}\text { UU+UL genotype } \\
\text { frequency (\%) }\end{array}$} & $\begin{array}{l}\text { Relative } \\
\text { risk }\end{array}$ & $\begin{array}{l}p \\
\text { (Fisher) }\end{array}$ \\
\cline { 2 - 4 } & Patients & $\begin{array}{l}\text { Control } \\
\text { subjects }\end{array}$ & & \\
\hline $\begin{array}{c}\text { Atherosclerosis } \\
\text { study }\end{array}$ & $\begin{array}{l}49 \\
(n=41)\end{array}$ & $\begin{array}{l}24 \\
(n=21)\end{array}$ & 3.36 & 0.037 \\
$\begin{array}{c}\text { Type 2 diabetes } \\
\text { studya }\end{array}$ & $\begin{array}{l}43 \\
(n=28)\end{array}$ & $\begin{array}{l}36 \\
(n=33)\end{array}$ & 1.31 & NS \\
\hline
\end{tabular}

${ }^{a}$ Data from [20] and [36], corrected for presence of macroangiopathy (Type 2 diabetic patients and control subjects), and impaired glucose tolerance (control subjects)

naires) and impaired glucose tolerance $(\sim 30 \%)$ [20], we chose as a control group all patients who had had coronary angiography done during the period $1977-1983$ at the University Hospital of Copenhagen, and in whom the coronary vessels were found to be absolutely normal. The reasons for referring these patients for coronary angiography were heterogeneous, i.e. primarily valvular disease, non-characteristic chest pain or arrythmias of unknown cause. The diagnoses of these patients at discharge from the hospital were distributed between nine different diagnostic categories (Table 4) [35]. Thus, selection of controls was not biased towards one type of non-atherosclerotic heart disease, which in itself might be associated positively or negatively with the genetic markers studied. The control subjects did not have typical symptoms of macrovascular disease, e.g. previous acute myocardial infarction or stroke, classical symptoms of angina pectoris or claudication of the lower extremities, as judged on the basis of the WHO cardiovascular survey questionnaire [33], modified for the purpose of this study. The control subjects were, in addition, examined before entry into the study, and no signs of macrovascular disease were found by palpation and auscultation of the large vessels. There were no functional signs of arterial insufficiency [36].

Subjects with elevated mean glucose concentrations $\left(\mathrm{HbA}_{1 \mathrm{c}}\right)$ or elevated fasting blood glucose concentrations were excluded from both atherosclerotic and non-atherosclerotic groups. The atherosclerotic patients were comparable to the control subjects with regard to age, body-weight and blood pressure [36].

One of the major findings of the study was that the U-allele-frequency was 2.5 times higher in atherosclerotic patients than in controls (Table 5). Not surprisingly, we found differences in sex distribution, smoking habits and lipoprotein-fraction pattern (high VLDL and low HDL) between the two groups (Table 6). These data confirm that the two groups were representative of the atherosclerotic and non-atherosclerotic populations, respectively. No association could be demonstrated however, between the $\mathrm{U}$-allele and known risk-factors, e.g. body-weight index, blood pressure, blood glucose, plas- 
ma triglyceride, plasma cholesterol or plasma lipoprotein-fractions.

In Pima Indians it has recently been reported that there was no relationship between ischaemic heart disease, as assessed by resting electrocardiograms (ECG), and the UU and UL genotypes (taken together), when small groups of Type 2 diabetic and nondiabetic subjects were studied [23].

\section{The U-allele and longevity}

Cardiovascular disease is a major cause of death in Caucasoid populations. Since the U-allele may be associated with atherosclerosis, its clinical importance may be simply investigated by analysing the allelic frequency of $U$ as a function of age in groups of unrelated individuals with normal glucose tolerance (Table 7). The allelic frequency of $U$ was lower in older age groups, although not significantly so (34-year-old versus 67 - and 85 -year-old, $p=0.097, \chi^{2}$ test) possibly due to small samples. It is likely that other factors are also important for longevity.

\section{Discussion}

In summary, the U-allele has recently been associated with Type 2 diabetes, diabetic hypertriglyceridaemia and atherosclerosis, and the L-allele with Type 1 diabetes.

Genetic markers for Type 1 diabetes outside the HLA-region have not been demonstrated previously, and it seems unnecessary to assume that other major susceptibility genes exist outside the HLA-region [37]. However, it cannot be excluded that the L-allele is a weak genetic marker for Type 1 diabetes in linkage disequilibrium with a hitherto unknown susceptibility locus on the short arm of chromosome 11.

In a large family, Type 1 diabetes was found in members with a particular HLA-haplotype, but all these members were also U-carriers (Fig. 2). Several non-diabetic members of this family, who carried the same HLA-haplotype were, however, also either homozygous or heterozygous for the L-allele [16]. Additional family studies are needed to show a segregation of the L-allele with Type 1 diabetes.

In the BB/Wistar rat, which spontaneously develops ketotic insulin-dependent diabetes, a recessive gene for lymphopenia is needed in addition to the RT1 ${ }^{\mathrm{u}}$-haplotype [38] (equivalent to an HLA-haplotype in man) for the development of Type 1 diabetes. The existence of a locus outside the HLA-region in man with similar effects on immuno-regulatory mechanisms cannot be ruled out.

\section{The U-allele and Type 2 diabetes, hypertriglyceridaemia and atherosclerosis}

The apparently contradictory results regarding the clinical associations of the U-allele are probably primarily due to heterogeneity of the study populations with regard to racial composition, glucose tolerance and occurrence of atherosclerosis. If patients with atherosclerosis were excluded from the sample of Type 2 diabetic patients studied by Owerbach and Nerup [20], there was no longer any statistically significant difference in $\mathrm{U}$-allele frequency between them and non-diabetic controls (Table 8). U-carriers have a relative risk of developing atherosclerosis which is two to three times higher than the relative risk (for the same individuals) of developing Type 2 diabetes (Table 8 [36]). In the study by MandrupPoulsen et al., the cardiovascular status was evaluated by coronary angiography [36], whereas the prevalence of atherosclerosis in the Type 2 diabetic patients [20] was assessed epidemiologically on the basis of questionnaires and hospital records. Thus, it is likely that the relative risk of developing Type 2 diabetes for U-carriers would in fact be lower than 1.31 if it were possible to exclude patients with abnormal coronary angiograms from the calculation.

Mandrup-Poulsen et al. [36] did not find a correlation between the plasma triglyceride-level and the U-allele. In the study by Jowett et al. [32], the patients were not characterized with regard to prevalence, extent or severity of atherosclerosis, and it is possible that the reported association between the U-allele and HTG in diabetes is secondary to a very high prevalence of macrovascular disease in these particular patients.

That atherosclerosis and Type 2 diabetes accompany each other in the same individuals seems to be established beyond doubt [39]. There is no evidence, however, to support the concept of a causal relationship between chronic hyperglycaemia and atherosclerotic macrovascular disease. It is conceivable that a common genetic background exists for these two diseases, predisposing to both atherosclerosis and Type 2 diabetes [39].

Genes for a number of risk-factors for the development of atherosclerosis have recently been mapped to two different chromosomes. The C3-complement type is associated with familial hypercholesterolaemia [40], and the gene coding for the C3-complement phenotype has been localized to chromosome 19 [41]. The gene for apo-lipoprotein $E$ is situated on the same chromosome and this gene together with other factors causes familial Type 3 hyperlipoproteinaemia [42]. Both of the referred hyperlipoproteinaemias are well-known risk-factors for the development of severe premature atherosclerosis. The apo-A1-lipoprotein gene has been assigned to the long arm of chromosome 11 [29]. Apo-lipoprotein A1 is the major constituent of HDL, low plasma levels of which confer increased risk of developing atherosclerosis.

No gene-product of the polymorphic insulin-gene flanking region is known. If this region is transcribed at all, the peptide formed must vary in length, every third amino-acid being glycine or proline depending on the direction of translation [7]. Interestingly, every third amino-acid in the $\alpha$-chain of collagen is in fact glycine 
[43]. An attractive hypothesis could be that differences in the structure of arterial vessel wall collagen may determine the susceptibility of an individual to atherogenic risk factors, assuming that the gene product of the polymorphic region is a collagen-like protein. Alternatively, the polymorphic region may be a genetic marker of atherosclerosis through linkage disequilibrium with an atherosclerosis-predisposing gene located close to the polymorphic region. The $45,000 \mathrm{bp}$ restriction fragment containing the insulin-gene and its flanking regions was not shown to contain other genes [7]. The apo-Al-lipoprotein gene is located on the long arm of chromosome 11, and linkage disequilibrium between the insulin-gene flanking region and the apo-A1-lipoprotein gene is impossible. The insulin-gene flanking polymorphism and the apo-A1-lipoprotein-related polymorphism do not co-segregate [44]. Mandrup-Poulsen et al. found no association between the U-allele and the C3 ${ }^{\mathrm{F}}$-complement type [36].

LL-homozygous individuals seem to have a low risk for developing atherosclerosis. This group is particularly interesting, since a higher prevalence of macrovascular disease has previously been demonstrated in LLhomozygous males than in LL-homozygous females [20]. In addition, LL-homozygous individuals showed differences in prevalence of atherosclerosis according to whether they were non-diabetic, had impaired glucose-tolerance or had Type 2 diabetes $(8 \%, 15 \%$, and $27 \%$, respectively [20]). In the study of the non-diabetic atherosclerotic patients [36], significantly higher plasma triglyceride concentrations and lower HDL concentrations were found in LL-homozygous patients with atherosclerosis than in LL-homozygous non-atherosclerotic individuals. In other words, the 'pure' effects of the cardiovascular risk factors are easier to demonstrate in LL-homozygous 'low-risk' individuals. This implies that epidemiological studies of the influence of different risk factors on the development of atherosclerosis, as well as intervention studies with impact on risk factors, may give inconclusive results if the study populations are not genetically characterized.

The finding of the U-allele as a genetic marker for atherosclerosis, in context with the known markers, underlines the concept that the environmental atherosclerosis-disposing risk factors act on the basis of a polygenic background, and suggests that genetic and clinical heterogeneity exists in atherosclerosis.

The application of modern DNA-technology in clinical research has provided us with new information about the genetic background of a number of diseases. Further development and use of this high technology analysis in clinical genetics will demand very stringent selection and characterization of patients and controls; this is particularly the case where environmental risk factors act on a genetic background. The studies reviewed here illustrate the epidemiological problems to be confronted when marker/disease associations are investigated in disorders of a mixed genetic/environ- mental aetiology, present not only in a small group of patients, but also in a non-symptomatic form in the background population.

Previous studies have been designed primarily as casecontrol studies, but technical improvements leading to increased capacity of restriction-fragment analysis may extend the use of this method to large-scale epidemiological investigations. Thus, it should be feasible to identify individuals of high risk for the development of atherosclerosis, by means of U/L-typing of families or even the general population, in which intervention with impact on risk factors would be relevant. The application of this genetic marker may also be used to detect heterogeneity within the spectrum of atherosclerotic macrovascular disease.

Acknowledgements. We are grateful to Mrs. A. Rafn for the preparation of this manuscript.

\section{References}

1. Editorial (1984) Molecular genetics for the clinician. Lancet 1: 257-259

2. Sanger $F$ (1959) Chemistry of insulin. Science 129: 1340-1344

3. Bell GI, Pictet RL, Rutter WJ, Cordell B, Tischer E, Goodman HM (1980) Sequence of the human insulin gene. Nature 284: 26-32

4. Owerbach D, Bell GI, Rutter WJ, Brown JA, Shows TB (1981) The insulin gene is located on the short arm of chromosome 11 in humans. Diabetes 30: 267-270

5. Harper ME, Ullrich A, Saunders GF (1981) Localization of the human insulin gene to the distal end of the short arm of chromosome 11. Proc Natl Acad Sci 78: 4458-4460

6. Bell GI, Pictet R, Rutter WJ (1980) Analysis of the regions flanking the human insulin gene and sequence of an Alu family member. Nucleic Acids Res 8: 4091-4109

7. Bell GI, Horita S, Karam JH (1984) A polymorphic locus near the human insulin gene is associated with insulin-dependent diabetes mellitus. Diabetes 33: 176-183

8. Schmid CW, Jelinek WR (1982) The Alu family of dispersed repetitive sequences. Science 216: 1065-1070

9. Stumph WE, Baez M, Beattie WG, Tsai M, O'Malley BW (1983) Characterization of deoxyribonucleic acid sequences of the $5^{r}$ and $3^{\prime}$ borders of the 100 kilobase pair ovalbumin gene domain. Biochemistry $22: 306-315$

10. Bell GI, Selby MJ, Rutter WJ (1982) The highly polymorphic region near the human insulin gene is composed of simply tandemly repeating sequences. Nature 295:31-35

11. Owerbach D, Aagaard L (1984) Analysis of a 1963-bp polymorphic region flanking the human insulin-gene. Gene 32: 475-479

12. Rotwein PS, Chirgwin J, Province M, Knowler WC, Pettitt DJ, Cordell B, Goodman HM, Permutt MA (1983) Polymorphism in the $5^{\prime}$ flanking region of the human insulin gene: A genetic marker for non-insulin-dependent diabetes. N Engl J Med 308: 65-71

13. Ullrich A, Dull TJ, Gray A, Philips JA, Peter S (1982) Variation in the sequence and modification state of the human insulin gene flanking regions. Nucleic Acids Res 10: 2225-2230

14. Owerbach D, Nerup J (1982) Restriction fragment length polymorphism of the insulin gene in diabetes mellitus. Diabetes 21 : 275-277

15. Svendsen PAa, Christiansen JS, Søegaard U, Welinder BS, Nerup J (1980) Rapid changes in chromatographically determined haemoglobin Alc induced by short term changes in glucose concentrations. Diabetologia 19: 130-136

16. Owerbach D, Poulsen S, Billesbølle P, Nerup J (1982) DNA inser- 
tion sequences near the insulin gene affect glucose regulation. Lancet 1: $880-883$

17. Permutt MA, Rotwein P, Andreone T, Ward WK, Porte D (1985) Islet beta-cell function and polymorphism in the $5^{\prime}$-flanking region of the human insulin gene. Diabetes 34: 311-314

18. Nerup J, Platz P, Andersen OO, Christy M, Lyngsøe J, Poulsen JE, Ryder LP, Nielsen LS, Thomsen M, Svejgaard A (1974) HLA antigens and diabetes mellitus. Lancet 2: 864-868

19. Rotwein P, Chyn R, Chirgwin J, Cordell B, Goodman HM, Permutt MA (1981) Polymorphism in the 5 '-flanking region of the human insulin gene and its possible relation to type 2 diabetes. Science 213: 1117-1120

20. Owerbach D, Johansen K, Billesbølle P, Poulsen S, Schroll M, Nerup J (1982) Possible association between DNA sequences flanking the insulin gene and atherosclerosis. Lancet 2: 1291-1293

21. Hitman GA, Jowett NI, Williams LG, Humphries S, Winter RM, Galton DJ (1984) Polymorphisms in the 5 -flanking region of the insulin gene and non-insulin-dependent diabetes. Clin Sci 66 : 383-388

22. Serjeantson SW, Owerbach D, Zimmet P, Nerup J, Thoma K (1983) Genetics of diabetes in Nauru: effects of foreign admixture, HLA antigens and the insulin-gene-linked polymorphism. Diabetologia 25:13-17

23. Knowler WC, Pettitt DJ, Vasquéz B, Rotwein PS, Andreone TL, Permutt MA (1984) Polymorphism in the $5^{\prime}$ flanking region of the human insulin gene. Relationships with non-insulin-dependent diabetes mellitus, glucose and insulin concentrations, and diabetes treatment in the Pima Indians. J Clin Invest 74: 2129-2135

24. Owerbach D, Thomsen B, Johansen K, Lamm LU, Nerup J (1983) DNA insertion sequences near the insulin gene are not associated with maturity-onset diabetes of young people. Diabetologia 25: $18-20$

25. Bell GI, Wainscoat JS, Old JM, Chlouverakis C, Keen H, Turner $\mathrm{RC}$, Weatherall DJ (1983) Maturity onset diabetes of the young is not linked to the insulin gene. Br Med J 286: 590-592

26. Johnston C, Owerbach D, Leslie RDG, Pyke DA, Nerup J (1984) Mason-type diabetes and DNA insertion polymorphism. Lancet 1: 280 (Letter)

27. Andreone T, Fajans S, Rotwein P, Skolnick M, Permutt MA (1985) Insulin gene analysis in a family with maturity-onset diabetes of the young. Diabetes 34: 108-114

28. Platz P, Jakobsen BK, Morling N, Ryder LP, Svejgaard A, Thomsen M, Christy M, Kromann H, Benn J, Nerup J, Green A, Hauge $M$ (1981) HLA-D and -DR antigens in genetic analysis of insulin dependent diabetes mellitus. Diabetologia 21: 108-115

29. Cheung P, Kao F, Law ML, Jones C, Puck TT, Chan L (1984) Localization of the structural gene for human apolipoprotein A-1 on the long arm of human chromosome 11. Proc Natl Acad Sci USA 81: $508-511$

30. Rees A, Shoulders CC, Stocks J, Galton DJ, Baralle FE (1983) DNA polymorphism adjacent to human apoprotein A-1 gene: Relation to hypertriglyceridaemia. Lancet 1: 444-446
31. Jowett NI, Hitman GA, Williams LG, Humphries S, Galton DJ (1983) Insulin gene polymorphism and hypertriglyceridaemia. Clin Sci 64: 37 (Abstract)

32. Jowett NI, Williams LG, Hitman GA, Galton DJ (1984) Diabetic hypertriglyceridaemia and related 5 ' flanking polymorphism of the human insulin gene. Br Med J 288: 96-99

33. Rose G, Blackburn H (1968) Cardiovascular survey methods. WHO Monograph Ser No 56. Geneva: World Health Organisation

34. Judkins MP (1967) Selective coronary arteriography. I. A percutaneous transfemoral technique. Radiology 89: 815-824

35. Mandrup-Poulsen T, Owerbach D, Mortensen SA, Johansen K, Meinertz H, Sørensen H, Nerup J (1984) A genetic marker for atherosclerosis? Lancet 1:1131

36. Mandrup-Poulsen T, Owerbach D, Mortensen SA, Johansen K, Meinertz H, Sørensen H, Nerup J (1984) DNA sequences flanking the insulin gene on chromosome 11 confer risk of atherosclerosis. Lancet 1: 250-252

37. Christy M, Mandrup-Poulsen T, Nerup J (1984) Genetic markers for insulin dependent diabetes mellitus. Ann Clin Res 16: 53-63

38. Buse JB, Ben-Nun A, Klein KA, Eisenbarth GS, Seidman JG, Jackson RA (1984) Specific class II histocompatibility gene polymorphism in BB rats. Diabetes 33: 700-703

39. Jarrett RJ (1984) Type 2 (non-insulin-dependent) diabetes mellitus and coronary heart disease - chicken, egg or neither? Diabetologia $26: 99-102$

40. Berg K, Heiberg A (1978) Linkage between familial hypercholesterolemia with xanthomatosis and the C3-polymorphism confirmed. Cytogenet Cell Genet 22:621-623

41. Whitehead AS, Salomon E, Chambers S, Bodmer WF, Povey S, Fey G (1982) Assignment of the structural gene for the third component of human complement to chromosome. 19. Proc Natl Acad Sci USA 79: 5021-5025

42. Uterman G, Vogelberg KH, Steinmetz A, Schoenborn W, Pruin N, Jaeschke M, Hees M, Canzler H (1979) Polymorphism of apolipoprotein E II. Genetics of hyperlipoproteinaemia type 3. Clin Genet 15: 37-62

43. Prockop DJ, Kivirikko KL, Tuderman L, Guzman NA (1979) The biosynthesis of collagen and its disorders. N Engl J Med 301: 13-23

44. Jowett NI, Rees A, Williams LG, Stocks J, Vella MA, Hitman GA, Katz J, Galton DJ (1984) Insulin and apolipoprotein A-1/C-III gene polymorphisms relating to hypertriglyceridaemia and diabetes mellitus. Diabetologia 27: 180-183

\section{Dr. Jørn Nerup}

Steno Memorial Hospital

Niels Steensens Vej 2

DK-2820 Gentofte

Denmark 